\title{
Nano Nickel-Cobalt Ferrite Catalysed One-Pot Multi-Component Synthesis of Xanthenediones and Acridinediones
}

\author{
Srividhya Maripi*, Raghu Babu Korupolu, Suri Babu Madasu \\ Department of Engineering Chemistry, A. U. College of Engineering (A), Andhra University, Visakhapatnam, India \\ Email: *vidyasri.chem@gmail.com
}

How to cite this paper: Maripi, S., Korupolu, R.B. and Madasu, S.B. (2017) Nano Nickel-Cobalt Ferrite Catalysed One-Pot Multi-Component Synthesis of Xanthenediones and Acridinediones. Green and Sustainable Chemistry, 7, 70-84.

https://doi.org/10.4236/gsc.2017.71006

Received: December 29, 2016

Accepted: February 25, 2017

Published: February 28, 2017

Copyright (๑) 2017 by authors and Scientific Research Publishing Inc. This work is licensed under the Creative Commons Attribution International License (CC BY 4.0).

http://creativecommons.org/licenses/by/4.0/

\begin{abstract}
1,8-Dioxo-octahydroxanthenes (4a-4f) and 1,8-dioxohexahydroacridines (5a5c) were synthesized by novel, simple and eco-friendly method with higher yields in the presence of magnetically separable nano nickel-cobalt ferrite catalyst $\left(\mathrm{Ni}_{0.5} \mathrm{Co}_{0.5} \mathrm{Fe}_{2} \mathrm{O}_{4}\right)$. The former, 1,8-dioxo-octahydroxanthenes have been synthesized from dimedone and different aromatic aldehydes, while the latter from this mixture are along with ammonium acetate. The main advantage of this method is that the nano catalyst can be reused up to five reaction cycles without losing the catalytic activity.
\end{abstract}

\section{Keywords}

1,8-Dioxo-Octahydroxanthenes, 1,8-Dioxohexahydroacridines, Nano Nickel Cobalt Ferrite Catalyst and Recyclable Catalyst

\section{Introduction}

One-pot, multi-component reactions (MCRs) are having momentous meaning due to formulation of mono product with elevated yields by the blending of two or more components in a one step process [1] [2]. The advantages of MCR's are atom economy, less time-consuming, easy purification process and avoiding protection-deprotection steps. Therefore, the design and development of efficient and green MCRs focused on a target molecule are one of the most significant challenges in organic synthesis in both medicine and industry.

Xanthenediones and acridinediones are having a significant role in the biological chemistry and organic synthesis [3]. 1,8-Dioxo-octahydroxanthenes are an important group of oxygen heterocycle family. 1,8-Dioxo-octahydroxanthenes 
are having phenyl substituted pyran ring which is fused on either side with two cyclohexanone rings. From past several years, biological and pharmaceutical industries are showing more interest towards synthesis of xanthenediones. Derivatives of xanthenediones will act as antiviral [4], antibacterial [5] and anti-inflammatory [6]. Xanthenediones are also utilised as antagonists for paralyzing action of zoxazolamine [7] and in photodynamic therapy [8]. Xanthenediones are the same structural units constituting various natural products [9] and used as versatile synthons, because of inherent reactivity of their pyran ring [10]. 1,8-Dioxohexahydroacridines are an important class of nitrogen heterocycle in which a phenyl substituted pyran ring is fused on either side with two cyclohexanone rings. 1,8-Acridinediones have 1,4-dihydropyridine (1, 4 DHP) parent nucleus, which is used for the treatment of cardiovascular diseases, such as, angina pectoris. These are also used as bronchodilator, anti-atherosclerotic, antitumor, gero-protective, hepatoprotective and antidiabetic agents [11].

For synthesis of xanthenes many methods are available; they are categorised based on starting compounds which include synthesis by cyclisation of polycyclic aryl triflate esters [12], intra-molecular trapping benzynes by phenols [13] and reaction of aryloxy magnesium halides with triethyl orthoformate [14] as well as cyclo-condensation of 2-hdroxyl aromatic aldehyde with 2-tetralone [15]. Condensation of aromatic aldehydes with 5,5-dimethyl-1,3-cyclohexanedione (dimedone) or 1,3-cyclohexanedione is one of the commonly utilized methods. There are different kinds of catalysts which have been reported for 1,8-dioxooctahy-droxanthenes synthesis. Some of the catalysts were specified in this section. They are $\mathrm{SiCl}_{4}$ [16], $\mathrm{SmCl}_{3}$ [17], $\mathrm{InCl}_{3} / \mathrm{P}_{2} \mathrm{O}_{5}$ [18], triethyl benzyl ammonium chloride (TEBA) [19], trichloro isocyanuric acid [20], p-dodecyl benzenesulfonic acid [21], diammonium hydrogen phosphate [22], tetramethylguanidine trifluoroacetate [23], $\mathrm{SbCl}_{3} / \mathrm{SiO}_{2}$ [24], trimethyl silyl chloride [25], ZnO-Acetyl chloride [26], $\mathrm{ZrOCl}_{2} \cdot 8 \mathrm{H}_{2} \mathrm{O}$ [27], Amberlyst- 15 [28], montmorillonite $\mathrm{K}-10$ [29] and cellulose sulfonic acid [30]. Aromatic aldehydes will condensate with 1,3-cyclohexanedione or 5,5-dimethyl-1,3-cyclohexanedione (dimedone) with ammonium acetate which is a most commonly used method for the synthesis of 1,8 dioxo-hexahydroacridines. Several catalysts have been reported for the synthesis of 1,8-dioxohexahydroacridines such as HY-Zeolite [31], Silica supported sulphuric acid [32], Bronsted acidic ionic liquid ([CMIM] $\left[\mathrm{CF}_{3} \mathrm{COO}\right]$ ) [33], methanesulfonic acid [34] and Poly(4-Vinylpyridinium) Hydrogen Sulfate [35].

The methods which are specified above are having its own advantages and merits, however many of these methods are unsatisfactory as they involve the use of halogenated solvents, unsatisfactory yields, harmful catalysts, catalyst loadings up to $30 \mathrm{~mol} \%$, prolonged reaction time and tedious experimental procedures. Development of clean and highly yielding and environmentally benign approaches is still desirable and much in demand. Therefore, it is necessary to develop the alternate methods for the synthesis of 1,8-dioxo-octahydroxanthenes and 1,8-dioxohexahydroacridines. The synthesis mechanism should involve simple in process, efficient, eco friendly with high yields with novel catalysts. 
In recent years, magnetic nano particles have emerged as a useful group of heterogeneous catalysts. Separation of magnetic nano particles is simple and an attractive alternative to filtration as it prevents catalytic loss and enhances reusability. The use of low cost and readily available species as catalyst plays a significant role for economic feasibility of the chemical process. The greener generation of nanoparticles and their eco-friendly applications in catalysis via magnetically recoverable and recyclable nano-catalysts for a variety of oxidation, reduction, and condensation reactions [36] [37] [38] [39], has made an incredible impact on the development of sustainable pathways. Magnetically recyclable nano catalysts and their use in benign media is an ideal merge for the development of sustainable methodologies in organic synthesis.

Therefore, in order to accomplish the novel, high yielding and eco-friendly synthetic process, minimizing the by-products, with minimum number of separate reaction steps, improving the yields, our research work was extended by the application of nano catalysts in MCRs, in this we report a clean and environmentally friendly approach to the synthesis of 1,8-dioxo-octahydroxanthenes and 1,8-dioxohexahydroacridines via multi-component reaction in the presence of nickel-cobalt ferrite nanoparticles.

Nickel cobalt ferrite nano particles are magnetically separable and having effective activity. Nickel cobalt ferrite nano particles are having advantages of multi cycling, easy work-up and clean reaction profiles apart from the lack of necessity ligands and in minimizing the organic waste generation when compared to the conventational catalytic systems. In this, we report xanthenediones and acridinediones synthesis by using magnetically separable nano nickel cobalt ferrite as heterogeneous catalyst. The synthesised derivatives were characterised by IR, ${ }^{1} \mathrm{H}$ NMR and Mass spectral data.

\section{Materials and Methods}

\subsection{Experimental}

Sigma Aldrich has been selected as vendor for sourcing the chemicals. All chemicals were purchased, which is having the purity not less than $99.9 \%$. Analytical Thin Layer Chromatography (TLC) was carried out by using silica gel 60 F254 pre-coated plates. Visualization was accomplished with UV lamp. All the products were characterized by their IR, ${ }^{1} \mathrm{H}$ NMR and Mass spectra. ${ }^{1} \mathrm{H}$ NMR was recorded on $300 \mathrm{MHz}$ in $\mathrm{CDCl}_{3} / \mathrm{DMSO}$, and the chemical shifts were reported in parts per million (ppm, $\delta$ ) downfield from the Tetramethyl silane (TMS).

\subsection{Preparation of the Nickel-Cobalt Ferrite Nano Catalyst}

Nickel-Cobalt Ferrites with formula $\mathrm{Ni}_{\mathrm{x}} \mathrm{Co}_{1-\mathrm{x}} \mathrm{Fe}_{2} \mathrm{O}_{4}(\mathrm{x}=1,0.75,0.5,0.25$ and 0$)$. In this $\mathrm{Ni}_{0.5} \mathrm{Co}_{0.5} \mathrm{Fe}_{2} \mathrm{O}_{4}(\mathrm{x}=0.5)$ has been chosen for the study and was synthesised by a chemical sol-gel co-precipitation method. In order to prepare $\mathrm{Ni}_{0.5} \mathrm{Co}_{0.5} \mathrm{Fe}_{2} \mathrm{O}_{4}$ nanoparticles, 0.05 moles of nickel nitrate, 0.05 moles of cobalt nitrate and 2 moles of iron nitrate are dissolved separately in a little amount of deionised water and then citric acid solution was prepared stoichiometric pro- 
portions. These two solutions were added in a 1:1 molar ratio and $\mathrm{P}^{\mathrm{H}}$ adjusted to 7 by the addition of ammonia and ethylene glycol is added. The aqueous mixture was heated to $60^{\circ} \mathrm{C}$, it was converted to gel and then temperature increased to $200^{\circ} \mathrm{C}$ finally to get powder. That powder was calcined to $600^{\circ} \mathrm{C}$ and then characterised with XRD and SEM.

\subsection{General Experimental Procedure for Synthesis of 1,8-Dioxo-Octahydroxanthenes}

Aromatic aldehyde $(5 \mathrm{mmol})$ and dimedone $(10 \mathrm{mmol})$ and nano nickel cobalt ferrite $\left(\mathrm{Ni}_{0.5} \mathrm{Co}_{0.5} \mathrm{Fe}_{2} \mathrm{O}_{4}, 20\right.$ mol\%) catalyst was taken in a round bottomed flask and the contents are dissolved in $5 \mathrm{~mL}$ of ethanol and $5 \mathrm{~mL}$ of water. Then the reaction mixture was stirred for $25 \mathrm{~min}$ at reflux temperature (Scheme 1). The completion of the reaction was monitored by TLC (n-hexane: ethyl acetate 4:1). After completion of the reaction the catalyst was separated by using an external strong Neodymium 35 magnet. Then $10 \mathrm{~mL}$ of ethanol was added to the reaction mixture and removal of solvent by rota vapor. After, the dried product was recrystallized from hot ethanol for several times to get the corresponding pure product dioxo-octahydroxanthenes in excellent yields. The purity of products was confirmed by IR, ${ }^{1} \mathrm{H}$ NMR and Mass spectras.

\subsection{General Experimental Procedure for Synthesis of 1,8-Dioxohexahydroacridines}

Aromatic aldehyde $(5 \mathrm{mmol})$, dimedone $(10 \mathrm{mmol})$, ammonium acetate (5 $\mathrm{mmol})$ and $20 \mathrm{~mol} \%$ nano nickel cobalt ferrite $\left(\mathrm{Ni}_{0.5} \mathrm{Co}_{0.5} \mathrm{Fe}_{2} \mathrm{O}_{4}\right)$ were taken in a $100 \mathrm{~mL}$ round bottomed flask and the contents are dissolved in $5 \mathrm{~mL}$ of ethanol and $5 \mathrm{~mL}$ of water. Then the reaction mixture was stirred for $40 \mathrm{~min}$ at reflux temperature (Scheme 2). After completion of the reaction the catalyst was separated by using an external strong Neodymium 35 magnet. Then $10 \mathrm{~mL}$ of ethanol was added to the reaction mixture and removal of solvent by rot a vapor. After, the dried product was recrystallized from hot ethanol for several times to get the corresponding pure product dioxohexahydroacridines in excellent yields. The purity of products was confirmed by IR, ${ }^{1} \mathrm{H}$ NMR and Mass spectras.

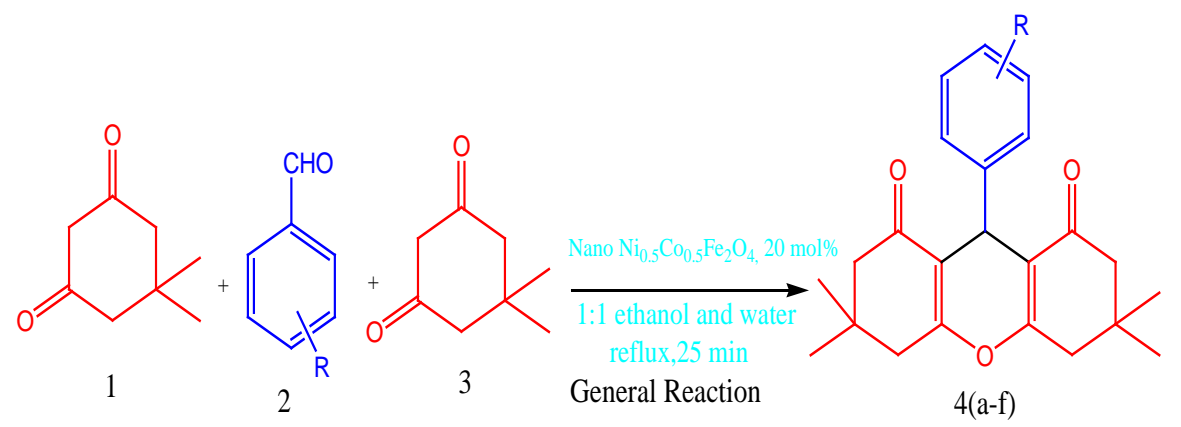

Scheme 1. A generalized scheme for synthesis of 1,8-dioxo-octahydroxanthene in presence of nano nickel cobalt ferrite catalyst by cyclocondensation of dimedone and aromatic aldehyde in water and ethanol solvent medium. $\left.(\mathrm{R}=\mathrm{a}) \mathrm{H}, \mathrm{b}) 4-\mathrm{OCH}_{3}, \mathrm{c}\right) 4-\mathrm{Cl}$, d) $4-\mathrm{NO}_{2}$, e) 2- $\mathrm{NO}_{2}$, f) 4-(2-pyridyl)). 


\section{Results and Discussions}

\subsection{Chemistry}

Initially a model reaction is conducted by using different solvents and different mol\% of catalyst for synthesis of 1,8-dioxo-octahydroxanthenes (Scheme 3) and 1,8-dioxohexahydroacridines (Scheme 4 ) to investigate the feasibility of the reaction.

First synthesis of 1,8-dioxo-octahydroxanthenes (Scheme 3), in this dimedone and benzaldehyde were taken in different solvents $\left(\mathrm{CH}_{2} \mathrm{Cl}_{2}, \mathrm{CCl}_{4}, \mathrm{CH}_{3} \mathrm{CN}\right.$, and $\mathrm{H}_{2} \mathrm{O}$, ethanol and ethanol + water) in the presence of nickel cobalt ferrite $\left(\mathrm{Ni}_{0.5} \mathrm{Co}_{0.5} \mathrm{Fe}_{2} \mathrm{O}_{4}\right)$ NPs and results were captured in Table 1 . It was clearly observed that low yield of products were obtained with $\mathrm{CH}_{2} \mathrm{Cl}_{2}, \mathrm{CCl}_{4}$, and $\mathrm{CH}_{3} \mathrm{CN}$ ) (35\%, 55\% and 40\%, Table 1 , entry $1-3$ ) respectively even after 7 hrs stirring. From Table 1, it is evident that low product yields (60\% and 65\%, entries 4 and 5) were obtained with water and ethanol independently. In a combination of 1:1

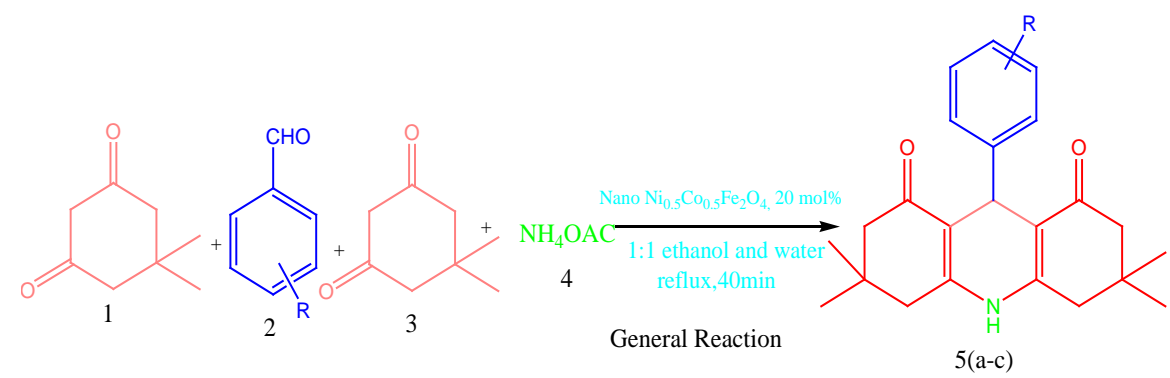

Scheme 2. A generalized reaction for synthesis of 1,8-dioxohexahydroacridines in presence of nano nickel cobalt ferrite catalyst by cyclocondensation of dimedone, aromatic aldehyde and ammonium acetate in ethanol and water solvent medium. $(\mathrm{R}=\mathrm{a}) \mathrm{H}, \mathrm{b})$ $4-\mathrm{Cl}$, c) $2-\mathrm{NO}_{2}$ ).<smiles>CC1(C)CC(=O)CC(C)(C)C1</smiles>

Scheme 3. A model reaction for synthesis of 1,8-dioxo-octahydroxanthene in presence of nano nickel cobalt ferrite catalyst by cyclocondensation of dimedone and benzaldehyde.<smiles>CC1(C)CC(=O)C2=C(C1)NC1=C(C(=O)CC(C)(C(C)(C)C)C1)C2c1ccccc1</smiles>

Scheme 4. A model reaction for synthesis of 1,8-dioxohexahydroacridines in presence of nano nickel cobalt ferrite catalyst by cyclocondensation of dimedone, benzaldehyde and ammonium acetate. 
$\mathrm{H}_{2} \mathrm{O}$ and EtOH, good yields of dioxo-octahydroxanthene derivatives were obtained with in 25 min (95\%, Table 1, entry 6).

Upon identifying the suitable solvent, next stage is to study the catalyst role on the reaction rate and product yield. To identify the appropriate catalyst, a series of parallel reactions were carried out with the catalytic amounts of different catalysts and the results are summarized in the Table 2 . When the reaction with $\mathrm{SiCl}_{4}, \mathrm{SmCl}_{3}$, Amberlyst-15, ZnO-acetyl chloride and p-dodecyl benzenesulfonic acid gave capable results with better yields (Table 2, entries 1, 2, 6, 7 and 8), and the best result was obtained with nickel cobalt ferrite $\left(\mathrm{Ni}_{0.5} \mathrm{Co}_{0.5} \mathrm{Fe}_{2} \mathrm{O}_{4}\right)$ nano particles in the $\mathrm{H}_{2} \mathrm{O}-\mathrm{EtOH}$ solvent system (Table 2, entry 10), and the reaction was completed within $25 \mathrm{~min}$.

After finding the suitable solvent and catalyst the model reaction is performed with different mol\% of $\mathrm{Ni}_{0.5} \mathrm{Co}_{0.5} \mathrm{Fe}_{2} \mathrm{O}_{4}$ catalyst and observed that 20 mol\% suitable to obtained maximum yield at neat condition (Table 3, entry 4). No change was observed on further enhancing the catalyst mol\%.

With the optimised reaction conditions in hand, the reaction was performed with different benzaldehydes (Scheme 1) with 20 mol\% $\mathrm{Ni}_{0.5} \mathrm{Co}_{0.5} \mathrm{Fe}_{2} \mathrm{O}_{4}$ NPs to explore the scope and generality of the present protocol and the results of these observations are summarized in Table 4. From the results, the aromatic aldehydes containing both electron releasing and withdrawing groups give products

Table 1. Optimisation of synthesis of 1,8-dioxo-octahydroxanthenes in presence of nickel cobalt ferrite at different solvent medium.

\begin{tabular}{ccccc}
\hline Entry & Solvent & Temperature $\left({ }^{\circ} \mathrm{C}\right)$ & Time & Yield (\%) \\
\hline 1 & $\mathrm{CH}_{2} \mathrm{Cl}_{2}$ & $35-40$ & $7 \mathrm{hrs}$ & 35 \\
2 & $\mathrm{CCl}_{4}$ & $60-65$ & $7 \mathrm{hrs}$ & 55 \\
3 & $\mathrm{CH}_{3} \mathrm{CN}$ & $80-85$ & $7 \mathrm{hrs}$ & 40 \\
4 & $\mathrm{H}_{2} \mathrm{O}$ & $95-100$ & $3 \mathrm{hrs}$ & 60 \\
5 & Ethanol & $75-78$ & $2.5 \mathrm{hrs}$ & 65 \\
6 & Ethanol $+\mathrm{H}_{2} \mathrm{O}$ & $100^{\circ}$ & $25 \mathrm{~min}$ & 95 \\
\hline
\end{tabular}

Table 2. Screening of various catalysts with $\mathrm{Ni}_{0.5} \mathrm{Co}_{0.5} \mathrm{Fe}_{2} \mathrm{O}_{4} \mathrm{NPs}$ in the synthesis.

\begin{tabular}{|c|c|c|c|c|c|}
\hline Entry & Catalyst & Conditions & Time (hrs) & Yield $(\%, w / w)$ & Reference \\
\hline 1 & $\mathrm{SiCl}_{4}$ & $\mathrm{CH}_{2} \mathrm{Cl}_{2} / 60^{\circ} \mathrm{C}-70^{\circ} \mathrm{C}$ & 3 & 92 & 16 \\
\hline 2 & $\mathrm{SmCl}_{3}$ & Solvent free $/ 120^{\circ} \mathrm{C}$ & 8 & 98 & 17 \\
\hline 3 & Cellulose sulfonic acid & Solvent free $/ 110^{\circ} \mathrm{C}$ & 6 & 95 & 30 \\
\hline 4 & Trimethyl silyl chloride & $\mathrm{CH}_{3} \mathrm{CN} /$ reflux & $8-10$ & $72-84$ & 25 \\
\hline 5 & $\mathrm{ZrOCl}_{2} \cdot 8 \mathrm{H}_{2} \mathrm{O}$ & Solvent free $/ 120^{\circ} \mathrm{C}$ & 0.66 & 95 & 27 \\
\hline 6 & Amberlyst-15 & $\mathrm{CH}_{3} \mathrm{CN} /$ reflux & 5 & $90-96$ & 28 \\
\hline 7 & $\mathrm{ZnO}$-acetyl chloride & & 16 & 96 & 26 \\
\hline 8 & p-dodecyl benzenesulfonic acid & Solvent free $/ 80^{\circ} \mathrm{C}$ & $10-60 \mathrm{~min}$ & $80-93$ & 21 \\
\hline 9 & Trichloro isocyanuric acid & Ethanol/reflux & 0.5 & 95 & 20 \\
\hline 10 & $\mathrm{Ni}_{0.5} \mathrm{Co}_{0.5} \mathrm{Fe}_{2} \mathrm{O}_{4} \mathrm{NPs}^{\prime}$ & Ethanol-water $/ 110^{\circ} \mathrm{C}$ & $25 \mathrm{~min}$ & 95 & Present work \\
\hline
\end{tabular}


Table 3. Effect of $\mathrm{Ni}_{0.5} \mathrm{Co}_{0.5} \mathrm{Fe}_{2} \mathrm{O}_{4}$ catalyst concentration on synthesis of 1,8-dioxooctahydroxanthenes.

\begin{tabular}{cccc}
\hline Entry & Catalyst $(\mathrm{mol} \%)$ & Time & Yield (\%) \\
\hline 1 & 5 & $120 \mathrm{~min}$ & 65 \\
2 & 10 & $90 \mathrm{~min}$ & 78 \\
3 & 15 & $60 \mathrm{~min}$ & 85 \\
4 & 20 & $25 \mathrm{~min}$ & 95 \\
5 & 25 & $25 \mathrm{~min}$ & 95 \\
6 & 30 & $25 \mathrm{~min}$ & 95 \\
\hline
\end{tabular}

Table 4. $\mathrm{Ni}_{0.5} \mathrm{Co}_{0.5} \mathrm{Fe}_{2} \mathrm{O}_{4}$ catalysed synthesis of 1,8-dioxo-octahydroxanthenes derivatives.

\begin{tabular}{ccccc}
\hline Entry & Product & $\mathrm{R}$ & Time (min) & Yield (\%, w/w ) \\
\hline 1 & $4 \mathrm{a}$ & $\mathrm{H}$ & 25 & $93 \%$ \\
2 & $4 \mathrm{~b}$ & $4-\mathrm{OCH}_{3}$ & 25 & $90 \%$ \\
3 & $4 \mathrm{c}$ & $4-\mathrm{Chloro}$ & 25 & $92 \%$ \\
4 & $4 \mathrm{~d}$ & $4-\mathrm{NO}_{2}$ & 25 & $96 \%$ \\
5 & $4 \mathrm{e}$ & $2-\mathrm{NO}_{2}$ & 25 & $95 \%$ \\
6 & $4 \mathrm{f}$ & $4-\left(2-\mathrm{pyridyl}^{2}\right.$ & 25 & $94 \%$ \\
\hline
\end{tabular}

with good yields, while electron withdrawing groups give products slightly better than releasing groups. The structures of synthesized 1,8-dioxo-octahydroxanthenes derivatives were confirmed by IR, $\mathrm{H}^{1} \mathrm{NMR}$ and Mass spectral analysis.

The plausible mechanism for the formation of 1,8-dioxo-octahydroxanthenes by using Nickel cobalt ferrite NPs is shown in Figure 1.

On the other hand a model reaction is conducted for synthesis of 1,8-dioxohexahydroacridines (Scheme 4), in this dimedone benzaldehyde and ammonium acetate were taken in different solvents (n-hexane, 1,4-dioxane, diethyl ether, $\mathrm{H}_{2} \mathrm{O}$, ethanol and ethanol + water) in the presence of $\mathrm{Ni}_{0.5} \mathrm{Co}_{0.5} \mathrm{Fe}_{2} \mathrm{O}_{4} \mathrm{NPs}$ and results are summarized in Table 5. It was clearly observed that low yield of product was obtained with $n$-hexane, 1,4-dioxane and diethyl ether (35\%, 40\% and 55\%, Table 5, entry $1-3$ ) respectively even after $10 \mathrm{hrs}$ stirring. From Table 5 , it is evident that low product yields (65\% and 70\%, Table 5, entries 4 and 5) were obtained with water and ethanol independently. In a combination of 1:1 $\mathrm{H}_{2} \mathrm{O}$ and $\mathrm{EtOH}$, good yields of dioxohexahydroacridine derivatives were obtained with in $40 \mathrm{~min}$ (96\%, Table 5, entry 6).

From the Table 5, 1:1 mixture of $\mathrm{H}_{2} \mathrm{O}$ and $\mathrm{EtOH}$ is a suitable solvent and then we have to find out the suitable catalyst. In order to find a suitable catalyst, a series of parallel reactions were carried out with the catalytic amounts of different catalysts and the results are summarized in the Table 6 . When the reactions are with silica supported sulphuric acid, methanesulfonic acid and $\mathrm{CuSO}_{4} \cdot 5 \mathrm{H}_{2} \mathrm{O}$ gave capable results with better yields (Table 6, entries 2, 4 and 5), and the best result was obtained with $\mathrm{Ni}_{0.5} \mathrm{Co}_{0.5} \mathrm{Fe}_{2} \mathrm{O}_{4} \mathrm{NPs}$ in the $\mathrm{H}_{2} \mathrm{O}-\mathrm{EtOH}$ solvent system (Table 6, entry 6), and the reaction was completed within 40 min with $96 \%$ yield. 


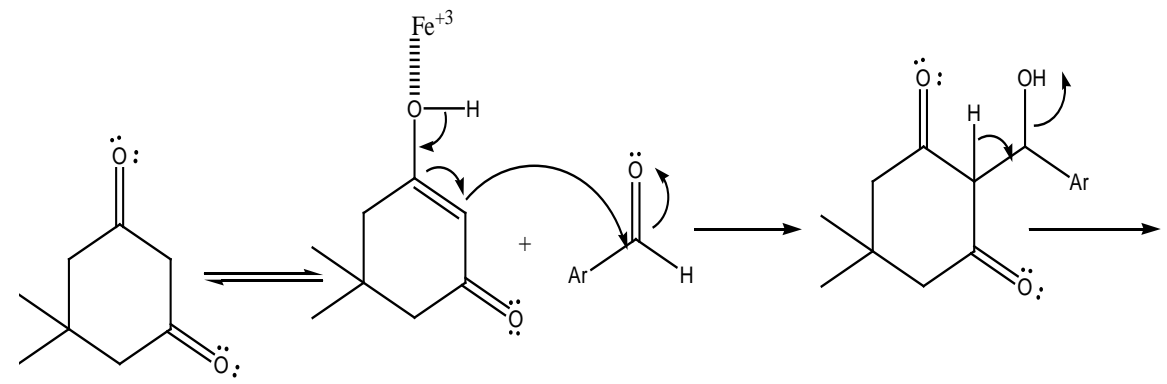

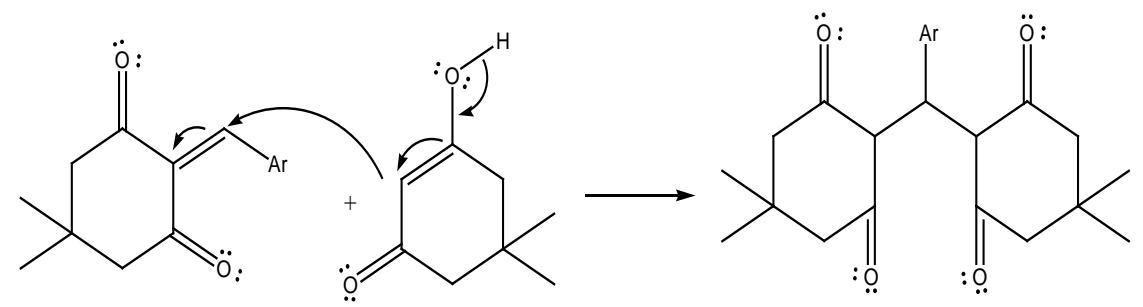

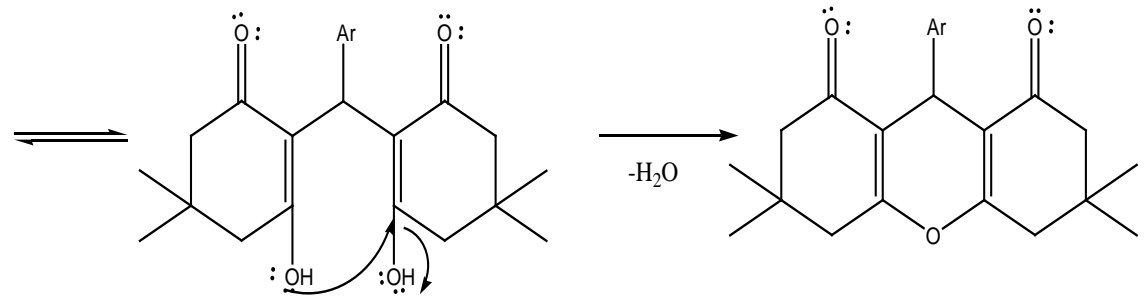

Figure: 1. Plausible mechanism for the formation of 1,8-dioxo-octahydroxanthenes.

Table 5. Optimisation of synthesis of 1,8-dioxohexahydroacridines in presence of nickel cobalt ferrite at different solvent medium.

\begin{tabular}{ccccc}
\hline Entry & Solvent & Temperature $\left({ }^{\circ} \mathrm{C}\right)$ & Time & Yield (\%) \\
\hline 1 & n-hexane & $68-70$ & $10 \mathrm{hrs}$ & 35 \\
2 & 1,4-dioxane & $98-102$ & $10 \mathrm{hrs}$ & 40 \\
3 & Diethyl erher & $34-36$ & $10 \mathrm{hrs}$ & 55 \\
4 & $\mathrm{H}_{2} \mathrm{O}$ & $95-100$ & $4 \mathrm{hrs}$ & 65 \\
5 & Ethanol & $75-78$ & $3 \mathrm{hrs}$ & 70 \\
6 & Ethanol $+\mathrm{H}_{2} \mathrm{O}$ & $94-96$ & $40 \mathrm{~min}$ & 96 \\
\hline
\end{tabular}

Table 6. Screening of various catalysts with nickel cobalt ferrite in the synthesis.

\begin{tabular}{cccccc}
\hline Entry & Catalyst & Conditions & Time (hrs) & Yield (\%,w/w) & Reference \\
\hline 1 & HY-Zeolite & Ethanol/reflux & $2.5-3.5$ & 90 & 31 \\
2 & Silica supported sulphuric acid & $\mathrm{H}_{2} \mathrm{O} / 70^{\circ} \mathrm{C}$ & 1.5 & 95 & 32 \\
3 & Bronsted acidic ionic liquid & Ethanol $/ 80^{\circ} \mathrm{C}$ & $1-1.5$ & 85 & 33 \\
4 & Methanesulfonic acid & Solvent free $/ 120^{\circ} \mathrm{C}$ & 1 & 92 & 34 \\
5 & $\mathrm{CuSO}_{4} \cdot 5 \mathrm{H}_{2} \mathrm{O}$ & EtOH- $\mathrm{H}_{2} \mathrm{O} / 80^{\circ} \mathrm{C}$ & 1.5 & 94 & - \\
6 & $\mathrm{Ni}_{0.5} \mathrm{Co}_{0.5} \mathrm{Fe}_{2} \mathrm{O}_{4} \mathrm{NPs}$ & EtOH$-\mathrm{H}_{2} \mathrm{O} / 100^{\circ} \mathrm{C}$ & 40 min & 96 & Present work \\
\hline
\end{tabular}

After finding the suitable solvent and catalyst the model reaction is performed with different mol\% of $\mathrm{Ni}_{0.5} \mathrm{Co}_{0.5} \mathrm{Fe}_{2} \mathrm{O}_{4}$ catalyst and observed that 20 mol\% suita- 
ble to obtained maximum yield at neat condition (Table 7, entry 4). No change was observed on further enhancing the catalyst mol\%.

Based on above results, this method extend to synthesis of different substituted 1,8-dioxohexahydroacridines with different aromatic aldehydes (Scheme 2), dimedone and ammonium acetate in presence of $\mathrm{Ni}_{0.5} \mathrm{Co}_{0.5} \mathrm{Fe}_{2} \mathrm{O}_{4}(20 \mathrm{~mol} \%)$ catalyst in $\mathrm{H}_{2} \mathrm{O}-\mathrm{EtOH}$ solvent system as shown in the Table 8 .

The plausible mechanism for the formation of 1,8-dioxohexahydroacridines by using nickel cobalt ferrite NPs is shown in Figure 2.

\subsection{Reusability of the Catalyst}

The reusability of nickel cobalt ferrite NPs is one of the most important advantages of this protocol that makes it useful for practical commercial applications. We have examined the recyclability of nickel cobalt ferrite NPs catalyst for the model reaction. Interestingly, the recovered catalyst could be reused for up to five cycles which is evident from Table 9. The catalyst was separated by using a magnet after completion of the reaction, washed with water followed by chloroform, dried in oven and reused for the next cycle.

\subsection{Spectral Data}

\subsubsection{Spectral Data of 1,8-Dioxo-Octahydroxanthenes}

1) 3,3,6,6-tetramethyl-9-(phenyl)-1,8-dioxo-octahydroxanthene

White solid, ${ }^{1} \mathrm{HNMR}\left(300 \mathrm{MHz}, \mathrm{CDCl}_{3}\right) \delta=0.96(\mathrm{~s}, 6 \mathrm{H}), 1.08(\mathrm{~s}, 6 \mathrm{H}), 2.02$ (d, $\mathrm{J}=16.2 \mathrm{~Hz}, 2 \mathrm{H}), 2.28(\mathrm{~d}, \mathrm{~J}=16.1 \mathrm{~Hz}, 2 \mathrm{H}), 2.51(\mathrm{~d}, \mathrm{~J}=17.3 \mathrm{~Hz}, 2 \mathrm{H}), 2.56(\mathrm{~d}, \mathrm{~J}=$ $17.5 \mathrm{~Hz}, 2 \mathrm{H}), 5.12(\mathrm{~s}, 1 \mathrm{H}), 7.05-7.28(\mathrm{~m}, 5 \mathrm{H})$; FTIR $\left(\mathrm{KBr}, \mathrm{cm}^{-1}\right): 3311,2982$, 1794, 1724, 1700, 1654, 1520, 1361, 1199; ESI-MS (m/z): $351\left(\mathrm{M}^{+}+1\right)$.

\section{2) 3,3,6,6-tetramethyl-9-(4-methoxy-phenyl)-1,8-dioxo-octahydroxanthenes}

Table 7. Effect of $\mathrm{Ni}_{0.5} \mathrm{Co}_{0.5} \mathrm{Fe}_{2} \mathrm{O}_{4}$ catalyst concentration on synthesis of 1,8-dioxooctahydroxanthenes.

\begin{tabular}{cccc}
\hline Entry & Catalyst (mol\%) & Time & Yield (\%) \\
\hline 1 & 5 & $180 \mathrm{~min}$ & 65 \\
2 & 10 & $120 \mathrm{~min}$ & 73 \\
3 & 15 & $90 \mathrm{~min}$ & 85 \\
4 & 20 & $40 \mathrm{~min}$ & 96 \\
5 & 25 & $40 \mathrm{~min}$ & 96 \\
6 & 30 & $40 \mathrm{~min}$ & 96 \\
\hline
\end{tabular}

Table 8. $\mathrm{Ni}_{0.5} \mathrm{Co}_{0.5} \mathrm{Fe}_{2} \mathrm{O}_{4}$ catalysed synthesis of 1,8-dioxohexahydroacridines.

\begin{tabular}{ccccc}
\hline Entry & Product & $\mathrm{R}$ & Time (min) & Yield (\%,w/w) \\
\hline 1 & $5 \mathrm{a}$ & $\mathrm{H}$ & $40 \mathrm{~min}$ & $92 \%$ \\
2 & $5 \mathrm{~b}$ & 4 -Chloro & $40 \mathrm{~min}$ & $95 \%$ \\
3 & $5 \mathrm{c}$ & 2-Nitro & $40 \mathrm{~min}$ & $94 \%$ \\
\hline
\end{tabular}


$\mathrm{NH}_{4} \mathrm{OAC}$ $\mathrm{NH}_{3}+\mathrm{ACOH}$

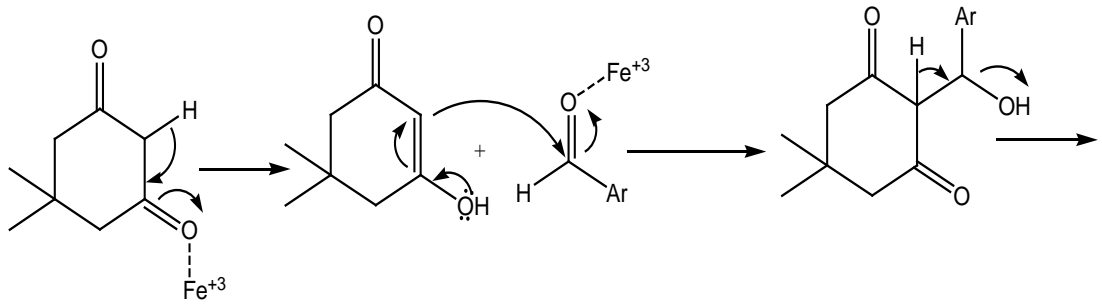<smiles>CCCCC1C(=O)CC(C)(C)CC1=O</smiles>

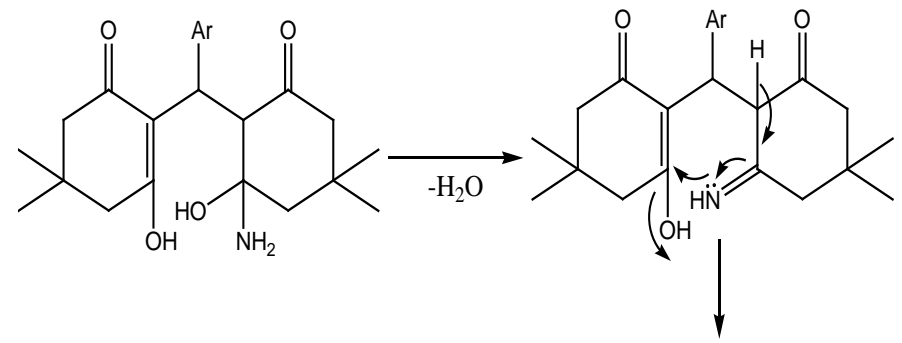<smiles>CC1(C)CC(=O)C2=C(C1)NC1=C(C(=O)CC(C)(C)C1)C2Br</smiles>

Figure 2. Plausible mechanism for the formation of 1,8-dioxohexahydroacridines.

Table 9. Productivity with re-cycle catalyst.

\begin{tabular}{ccc}
\hline Entry & Catalyst re-use & Yield $(\%, w / w)$ \\
\hline 1 & $1^{\text {st }}$ cycle & 94 \\
2 & $2^{\text {nd }}$ cycle & 92 \\
3 & $3^{\text {rd }}$ cycle & 90 \\
4 & $4^{\text {th }}$ cycle & 89 \\
5 & $5^{\text {th }}$ cycle & 87 \\
\hline
\end{tabular}

White solid, ${ }^{1} \mathrm{HNMR}\left(300 \mathrm{MHz}, \mathrm{CDCl}_{3}\right) \delta=0.98(\mathrm{~s}, 6 \mathrm{H}), 1.10$ (s, 6H), 2.04 (d, $\mathrm{J}=16.1 \mathrm{~Hz}, 2 \mathrm{H}), 2.26(\mathrm{~d}, \mathrm{~J}=16.2 \mathrm{~Hz}, 2 \mathrm{H}), 2.50$ (d, J = 17.4 Hz, 2H), 2.54 (d, J = $17.3 \mathrm{~Hz}, 2 \mathrm{H}), 3.82$ (s, 3H), $5.46(\mathrm{~s}, 1 \mathrm{H}), 6.84$ (d, 2H), 7.02 (d, 2H); FTIR (KBr, $\left.\mathrm{cm}^{-1}\right): 3030,2970,2873,1679,1650,1511,1460,1372,1261,1193,1165,1138$, 1030, 841; ESI-MS $(\mathrm{m} / z): 381\left(\mathrm{M}^{+}+1\right)$.

\section{3) 3,3,6,6-tetramethyl-9-(4-chloro-phenyl)-1,8-dioxo-octahydroxanthenes}

White solid, ${ }^{1} \mathrm{H}$ NMR (300 MHz, $\mathrm{CDCl}_{3}$ ) $\delta=0.92$ (s, 6H), 1.08 (s, 6H), 2.09 (d, $\mathrm{J}=16.1 \mathrm{~Hz}, 2 \mathrm{H}), 2.24(\mathrm{~d}, \mathrm{~J}=16.1 \mathrm{~Hz}, 2 \mathrm{H}), 2.51(\mathrm{~d}, 2 \mathrm{H}), 2.53(\mathrm{~d}, \mathrm{~J}=17.6 \mathrm{~Hz}$, $2 \mathrm{H}), 4.52(\mathrm{~s}, 1 \mathrm{H}), 7.16(\mathrm{~d}, \mathrm{~J}=8.3 \mathrm{~Hz}, 2 \mathrm{H}), 7.24(\mathrm{~d}, \mathrm{~J}=8.2 \mathrm{~Hz}, 2 \mathrm{H})$; FTIR (KBr, $\left.\mathrm{cm}^{-1}\right): 3020,2985,2952,1680,1660,1480,1361,1200,1198,1160,1090,1000$, 
850; ESI-MS $(\mathrm{m} / \mathrm{z}): 385.5\left(\mathrm{M}^{+}+1\right)$

4) 3,3,6,6-tetramethyl-9-(4-nitro-phenyl)-1,8-dioxo-octahydroxanthenes

Yellow solid, ${ }^{1} \mathrm{H}$ NMR (300 MHz, $\left.\mathrm{CDCl}_{3}\right) \delta=0.94(\mathrm{~s}, 6 \mathrm{H}), 1.04(\mathrm{~s}, 6 \mathrm{H}), 2.06$ $(\mathrm{d}, \mathrm{J}=16.2 \mathrm{~Hz}, 2 \mathrm{H}), 2.26(\mathrm{~d}, \mathrm{~J}=16.1 \mathrm{~Hz}, 2 \mathrm{H}), 2.52(\mathrm{~d}, 2 \mathrm{H}), 2.54(\mathrm{~d}, \mathrm{~J}=17.6 \mathrm{~Hz}$, 2H), $4.54(\mathrm{~s}, 1 \mathrm{H}), 7.16(\mathrm{~d}, \mathrm{~J}=8.3 \mathrm{~Hz}, 2 \mathrm{H}), 7.26(\mathrm{~d}, \mathrm{~J}=8.2 \mathrm{~Hz}, 2 \mathrm{H})$; FTIR $(\mathrm{KBr}$, $\left.\mathrm{cm}^{-1}\right)$ : 3030, 2980, 2956, 1685, 1661, 1515, 1465, 1361, 1344, 1292, 1201, 1160, 1090, 850; ESI-MS $(\mathrm{m} / \mathrm{z}): 396\left(\mathrm{M}^{+}+1\right)$.

5) 3,3,6,6-tetramethyl-9-(2-nitro-phenyl)-1,8-dioxo-octahydroxanthenes

Yellow solid, ${ }^{1} \mathrm{H}$ NMR $\left(300 \mathrm{MHz}, \mathrm{CDCl}_{3}\right) \delta=0.92(\mathrm{~s}, 6 \mathrm{H}), 1.08(\mathrm{~s}, 6 \mathrm{H}), 2.02(\mathrm{~d}$, $\mathrm{J}=16.1 \mathrm{~Hz}, 2 \mathrm{H}), 2.24(\mathrm{~d}, \mathrm{~J}=16.2 \mathrm{~Hz}, 2 \mathrm{H}), 2.46(\mathrm{~d}, \mathrm{~J}=17.4 \mathrm{~Hz}, 2 \mathrm{H}), 2.52(\mathrm{~d}, \mathrm{~J}=$ $17.1 \mathrm{~Hz}, 2 \mathrm{H}), 5.46(\mathrm{~s}, 1 \mathrm{H}), 7.04-7.28(\mathrm{~m}, 4 \mathrm{H})$; FTIR $\left(\mathrm{KBr}, \mathrm{cm}^{-1}\right)$ : 3020, 2972, 2870, 1680, 1650,1512, 1466, 1372, 1260, 1190, 1100, 1030, 841, 574; ESI-MS $(\mathrm{m} / \mathrm{z}): 396\left(\mathrm{M}^{+}+1\right)$.

6) 3,3,6,6-tetramethyl-9-(4-(2-pyridyl)-phenyl)-1,8-dioxo-octahydroxanthenes

White solid, ${ }^{1} \mathrm{H}$ NMR (300 MHz, $\left.\mathrm{CDCl}_{3}\right) \delta=0.96(\mathrm{~s}, 6 \mathrm{H}), 1.12(\mathrm{~s}, 6 \mathrm{H}), 2.18$ (d, $\mathrm{J}=16.7 \mathrm{~Hz}, 2 \mathrm{H}), 2.23(\mathrm{~d}, \mathrm{~J}=17 \mathrm{~Hz}, 2 \mathrm{H}), 2.52(\mathrm{~d}, \mathrm{~J}=17.8 \mathrm{~Hz}, 2 \mathrm{H}), 2.52(\mathrm{~d}, \mathrm{~J}=$ $17.5 \mathrm{~Hz}, 2 \mathrm{H}), 5.42(\mathrm{~s}, 1 \mathrm{H}), 7.04-7.28(\mathrm{~m}, 4 \mathrm{H}), 7.12-7.38$ (m, 4H); FTIR (KBr, $\left.\mathrm{cm}^{-1}\right): 3030,2962,2930,2872,1680,1654,1610,1419,1374,1299,1248,1198$, 1160, 1090, 868, 841; ESI-MS ( $m / z): 428\left(\mathrm{M}^{+}+1\right)$.

\subsubsection{Spectral Data of 1,8-Dioxohexahydroacridines}

1) 3,3,6,6-tetramethyl-9-phenyl-3,4,6,7,9,10 hexahydroacridine-1,8-dione

White solid, ${ }^{1} \mathrm{HNMR}\left(300 \mathrm{MHz}, \mathrm{CDCl}_{3}\right) \delta=9.28(\mathrm{~s}, 1 \mathrm{H}), 4.8(\mathrm{~s}, 1 \mathrm{H}), 0.92(\mathrm{~s}$, 6H), $1.02(\mathrm{~s}, 6 \mathrm{H}), 1.94(\mathrm{~d}, \mathrm{~J}=21.5 \mathrm{~Hz}, 2 \mathrm{H}), 2.12(\mathrm{~d}, \mathrm{~J}=21.5 \mathrm{~Hz}, 2 \mathrm{H}), 2.32(\mathrm{~d}, \mathrm{~J}=$ $22.82 \mathrm{H}), 2.4(\mathrm{~d}, 21.5 \mathrm{~Hz}, 2 \mathrm{H}), 7.05-7.28(\mathrm{~m}, 5 \mathrm{H})$; FTIR $\left(\mathrm{KBr}, \mathrm{cm}^{-1}\right)$ : 3433, 3279, $3205,3063,2955,2932,1630,1605,1481,1365,1210,1142$; ESI-MS $(\mathrm{m} / \mathrm{z}): 350$ $\left(\mathrm{M}^{+}+1\right)$.

2) 3,3,6,6-tetramethyl-9-(4-chlorophenyl)-3,4,6,7,9,10 hexahydroacridine1,8-dione

Yellow solid, ${ }^{1} \mathrm{H}$ NMR (300 MHz, $\left.\mathrm{CDCl}_{3}\right) \delta=9.16(\mathrm{~s}, 1 \mathrm{H}), 5.02(\mathrm{~s}, 1 \mathrm{H}), 1.02$ (s, 6H), $1.10(\mathrm{~s}, 6 \mathrm{H}), 2.02(\mathrm{~d}, \mathrm{~J}=16.1 \mathrm{~Hz}, 2 \mathrm{H}), 2.23(\mathrm{~d}, \mathrm{~J}=16.3 \mathrm{~Hz}, 2 \mathrm{H}), 2.42(\mathrm{~d}, \mathrm{~J}=$ $17.3 \mathrm{~Hz}, 2 \mathrm{H}), 2.52(\mathrm{~d}, \mathrm{~J}=17.1 \mathrm{~Hz}, 2 \mathrm{H}), 7.24(\mathrm{~d}, \mathrm{~J}=8 \mathrm{~Hz}, 2 \mathrm{H}), 7.26(\mathrm{~d}, \mathrm{~J}=5.7 \mathrm{~Hz}$, 2H); FTIR (KBr, cm $\left.{ }^{-1}\right): 3430,3275,3170,3030,2955,16501609$ 1485, 1398, 1360 850; ESI-MS $(\mathrm{m} / \mathrm{z}): 384\left(\mathrm{M}^{+}+1\right)$.

3) 3,3,6,6-tetramethyl-9-(2-nitrophenyl)-3,4,6,7,9,10 hexahydroacridine-

\section{1,8-dione}

White solid, ${ }^{1} \mathrm{H}$ NMR $\left(300 \mathrm{MHz}, \mathrm{CDCl}_{3}\right) \delta=8.98(\mathrm{~s}, 1 \mathrm{H}), 5.0(\mathrm{~s}, 1 \mathrm{H}), 0.98(\mathrm{~s}$, $6 \mathrm{H}), 1.12(\mathrm{~s}, 6 \mathrm{H}), 2.04(\mathrm{~d}, \mathrm{~J}=25.1 \mathrm{~Hz}, 2 \mathrm{H}), 2.26(\mathrm{~d}, \mathrm{~J}=22.6 .2 \mathrm{~Hz}, 2 \mathrm{H}), 2.50(\mathrm{~d}, \mathrm{~J}=$ $21.4 \mathrm{~Hz}, 2 \mathrm{H}), 2.54(\mathrm{~d}, \mathrm{~J}=22.3 \mathrm{~Hz}, 2 \mathrm{H}), 7.06-7.28(\mathrm{~m}, 4 \mathrm{H})$; FTIR $\left(\mathrm{KBr}, \mathrm{cm}^{-1}\right)$ : $3440,3274,3170,3030,2970,2873,1685,1650,1512,1460,1375,1250$, 1190,1100, 1030, 841; ESI-MS (m/z): $380\left(\mathrm{M}^{+}+1\right)$.

\section{Conclusion}

Based on the above conclusion it was concluded that, we have described a novel, 
efficient, multi-component one-pot green synthetic method using nano nickel cobalt ferrite catalyst and ethanol and water as a solvent. The novel and synthetic utility of this method is established in the efficient synthesis of 1,8-dioxooctahedraxanthenes and 1,8-dioxohexahydroacridines derivatives. The advantages of this method include its simplicity of operation, cleaner reaction, and being good to excellent yields. Further, the purification of the product is simple involving filtration. The catalyst is easily separated by using external magnet and is reusable up to five cycles.

\section{Acknowledgements}

The corresponding author is grateful to CSIR, New Delhi for supporting through fellowship (JRF \& SRF) \& Department of Engineering chemistry, AUCE (A), Andhra University, and Visakhapatnam for providing general lab facilities. The corresponding author is also grateful to Prof. K. Raghu Babu for his valuable \& constant support.

\section{References}

[1] Ugi, I. (2001) Recent Progress in the Chemistry of Multi Component Reactions. Pure and Applied Chemistry, 73, 187-191. https://doi.org/10.1351/pac200173010187

[2] Domling, A. (20060 Recent Developments in Isocyanide Based Multicomponent Reactions in Applied Chemistry. Chemical Reviews, 106, 17-89. https://doi.org/10.1021/cr0505728

[3] Di Stilo, A., Visentin, S., Cena, C., Gasco, A.M., Ermondi, G. and Gasco, A. (1998) New 1,4-Dihydropyridines Conjugated to Furoxanyl Moieties, Endowed with Both Nitric Oxide-Like and Calcium Channel Antagonist Vasodilator Activities. Journal of Medicinal Chemistry, 41, 5393-5401. https://doi.org/10.1021/jm9803267

Thull, U. and Testa, B. (1994) Screening of Unsubstituted Cyclic Compounds as Inhibitors of Monoamine Oxidases. Biochemical Pharmacology, 47, 2307-2310. https://doi.org/10.1016/0006-2952(94)90271-2

Tu, S., Miao, C., Fang, F., Youjian, F., Li. T., Zhuang, Q., Zhang, X., Zhu, S. and Shi, D. (2004) New Potential Calcium Channel Modulators: Design and Synthesis of Compounds Containing Two Pyridine, Pyrimidine, Pyridone, Quinoline and Acridine Units under Microwave Irradiation. Bioorganic \& Medicinal Chemistry Letters, 14, 1533-1536. https://doi.org/10.1016/j.bmcl.2003.12.092

[4] Lamberk, R.W., Martin, J.A., Merrett, J.H., Parkes, K.E.B. and Thomas, G.J. (1997) PCT Int. Appl. WO 9706178, 1997, Chemical Abstract, Vol. 126, 1997, p. 212377y.

[5] Hideu, T. (1981) JPn. Tokkyo Koho JP 56005480, 1981, Chemical Abstract, Vol. 95, 1981, 80922b.

[6] Poupelin, J.P., Saint-Ruf, G., Lacroix, R., Narcisse, G., Foussard-Blanpin, O. and Uchida-Ernouf, G. (1978) Synthesis and Antiinflammatory Properties of Bis(2- Hydroxy, 1-Naphthyl) Methane Derivatives. European Journal of Medicinal Chemistry, 13, 67-71.

[7] Saint-Ruf, G., Huynh-Trong-Hieu and Poupelin, J.P. (1975) The Effect of Dibenzoxanthenes on the Paralyzing Action of Zoxazolamine. Naturwissenschaften, 62, 584-585. https://doi.org/10.1007/BF01166986

[8] Ion, R.M., Planner, A., Wiktorowicz, K. and Frackowiak, D. (1998) The Incorporation of Various Porphyrins into Blood Cells Measured via Flow Cytometry, Absorp- 
tion and Emission Spectroscopy. Acta Biochimica Polonica, 45, 833-845.

[9] Hatakeyma, S., Ochi, N., Numata, H. and Takano, S.J. (1988) A New Route to Substituted 3-Methoxycarbonyldihydropyrans; Enantioselective Synthesis of (-)-Methyl Elenolate. Journal of the Chemical Society, Chemical Communications, 17, 1202 1204. https://doi.org/10.1039/C39880001202

[10] Callaghan, C.N.O. and McMurry, T.B.H. (1995) Synthetic Reactions of Methyl XY-Carbonyl-4H-1-benzopyran-4yl Cyanoethanoate. Journal of Chemical Research, Synopses, 214-218.

[11] Shan, R., Velazquez, C. and Knaus, E. (2004) Syntheses, Calcium Channel Agonist-Antagonist Modulation Activities, and Nitric Oxide Release Studies of Nitrooxyalkyl 1,4-Dihydro-2,6-dimethyl-3-nitro-4-(2,1,3-benzoxadiazol-4-yl)pyridine-5-carboxylate Racemates, Enantiomers, and Diastereomers. Journal of Medicinal Chemistry, 47, 254-261. https://doi.org/10.1021/jm030333h

[12] Wang, J.Q. and Harvey, R.G. (2002) Synthesis of Polycyclic Xanthenes and Furans via Palladium-Catalyzed Cyclization of Polycyclic Aryltriflate Esters. Tetrahedron, 58, 5927-5931. https://doi.org/10.1016/S0040-4020(02)00534-3

[13] Knight, D.W. and Little, P.B. (1998) The First High-Yielding Benzyne Cyclisation Using a Phenolic Nucleophile: A New Route to Xanthenes. Synlett, 10, 1141-1143. https://doi.org/10.1055/s-1998-1878

[14] Casiraghi, G., Casnati, G. and Cornia, M. (1973) Regiospecific Reactions of Phenol Salts: Reaction-Pathways of Alkylphenoxy-Magnesiumhalides with Triethylorthoformate. Tetrahedron Letter, 14, 679-682. https://doi.org/10.1016/S0040-4039(00)72432-4

[15] Jha, A. and Beal, J. (2004) Convenient Synthesis of 12H-Benzo[a]xanthenes from 2-Tetralone. Tetrahedron Letter, 45, 8999-9001. https://doi.org/10.1016/j.tetlet.2004.10.046

[16] Soliman, H.A. and Salama, T.A. (2013) Silicon-Mediated Highly Efficient Synthesis of 1,8-Dioxo-Octahydroxanthenes and Their Transformation to Novel Functionalized Pyrano-Tetrazolo[1,5-a] Azepine Derivatives. Chinese Chemical Letters, 24, 404-406. https://doi.org/10.1016/j.cclet.2013.03.021

[17] Llangovan, A., Malayappasamy, S., Muralidharan, S. and Maruthamuthu, S. (2011) A Highly Efficient Green Synthesis of 1,8-Dioxo-Octahydroxanthenes. Chemistry Central Journal, 5, 81. https://doi.org/10.1186/1752-153X-5-81

[18] Verma, G.K., Raghuvanshi, K., Verma, R.K., Dwivedi, P. and Singh, M.S. (2011) An Efficient One-Pot Solvent-Free Synthesis and Photophysical Properties of 9Aryl/Alkyl-Octahydroxanthene-1,8-Diones. Tetrahedron, 67, 3698-3704. https://doi.org/10.1016/j.tet.2011.03.078

[19] Wang, X.S., Shi, D.Q., Li, Y.L., Chen, H., Wei, X.Y. and Zong, Z.M. (2005) A Clean Synthesis of 1-Oxo-Hexahydro-Xanthene Derivatives in Aqueous Media Catalyzed by TEBA. Synthetic Communications, 35, 97-104. https://doi.org/10.1081/SCC-200046510

[20] Bigdeli, M.A., Nemati, F., Mahdavinia, G.H. and Doostmohammadi, H.A. (2009) Series of 1,8-Dioxooctahydroxanthenes Are Prepared Using Trichloroisocyanuric Acid. Chinese Chemical Letters, 20, 1275-1278. https://doi.org/10.1016/j.cclet.2009.06.024

[21] Jin, T.S., Zhang, J.S., Xiao, J.C., Wang, A.Q. and Li, T.S. (2006) Clean Synthesis of 1,8-Dioxo-Octahydroxanthene Derivatives Catalyzed by p-Dodecylbenezenesulfonic Acid in Aqueous Media. Ultrasonics Sonochemistry, 3, 220-224. https://doi.org/10.1016/j.ultsonch.2005.04.002

[22] Darvish, F., Balalaei, S., Chadegani, F. and Salehi, P. (2007) Diammonium Hydro- 
gen Phosphate as a Neutral and Efficient Catalyst for Synthesis of 1,8-Dioxo-Octahydroxanthene Derivatives in Aqueous Media. Synthetic Communications, 37, 1059-1066. https://doi.org/10.1080/00397910701196520

[23] Rahmati, A. (2010) A Rapid and Efficient Method for the Synthesis of 14H-Dibenzo[a.j]Xanthenes, Aryl-5H-Dibenzo [b.i]Xanthene-5,7,12,14-(13H)-Tetraone and 1,8-Dioxo-Octahydroxanthenes by Acidic Ionic Liquid. Chinese Chemical Letter, $21,761-764$.

[24] Zhang, Z.H. and Liu, Y.H. (2008) Antimony Trichloride $/ \mathrm{SiO}_{2}$ Promoted Synthesis of 9-Ary-3, 4, 5, 6, 7, 9-Hexahydroxanthene-1,8-Diones. Catalysis Communications, 9, 1715-1719. https://doi.org/10.1016/j.catcom.2008.01.031

[25] Kantevari, S., Bantu, R. and Nagarapu, L. (2006) TMSCl Mediated Highly Efficient One-Pot Synthesis of Octahydroquinazolinone and 1,8-Dioxo-Octahydroxanthene Derivatives. Arkivoc, 16, 136-148.

[26] Maghsoodlou, M.T., Habibi-Khorassani, S.M., Shahkarami, Z., Maleki, N. and Rostamizadeh, M. (2010) An Efficient Synthesis of 2,2'-Arylmethylene Bis(3-Hydroxy5,5-Di-Methyl-2-Cyclohexene-1-One) and 1,8-Dioxo-Octahydroxanthenes Using $\mathrm{ZnO}$ and $\mathrm{ZnO}$-Acetyl Chloride. Chinese Chemical Letters, 21, 686-689. https://doi.org/10.1016/j.cclet.2010.02.005

[27] Lü, H.Y., Li, J.J. and Zhang, Z.H. (2009) $\mathrm{ZrOCl}_{2} \cdot 8 \mathrm{H}_{2} \mathrm{O}$ : A Highly Efficient Catalyst for the synthesis of 1,8-Dioxo-Octahydroxanthene Derivatives under Solvent-Free Conditions. Applied Organometalic Chemistry, 23, 165-169. https://doi.org/10.1002/aoc.1488

[28] Das, B., Thirupathi, P., Mahender, I., Reddy, V.S. and Rao, Y.K. (2006) Amberlyst-15: An Efficient Reusable Heterogeneous Catalyst for the Synthesis of 1,8-Dioxo-Octahydroxanthenes and 1,8-Dioxo-Decahydroacridines. Journal of Molecular Catalysis A: Chemical, 247, 233-239. https://doi.org/10.1016/j.molcata.2005.11.048

[29] Dabiri, M., Azimi, S.C. and Bazgir, A. (2008) One-Pot Synthesis of Xanthene Derivatives under Solvent-Free Conditions. Chemical Papers, 62, 522-526. https://doi.org/10.2478/s11696-008-0050-y

[30] Oskooie, L.H., Tahershamsi, A., Heravi, M.M. and Baghernejad, B. (2010) Cellulose Sulfonic Acid: An Efficient Heterogeneous Catalyst for the Synthesis of 1,8-Dioxo-Octa- hydroxanthenes. E-Journal of Chemistry, 7, 717-720. https://doi.org/10.1155/2010/936107

[31] Nikpassand, M., Mamaghani, M. and Tabatabaeian, K. (2009) An EfficientonePotthree-Component Synthesis of Fused1, 4-Dihydropyridines Using HY-Zeolite. Molecules, 14, 1468-1474. https://doi.org/10.3390/molecules14041468

[32] Sheik Mansoor, S., Aswin, K., Logaiya, K. and Sudhan S.P.N. (2014) Aqua-Mediated Synthesis of Acridinediones with Reusable Silica-Supported Sulfuric Acid as an Efficient Catalyst. Journal of Taibah University for Science, 8, 265-227.

https://doi.org/10.1016/j.jtusci.2014.03.003

[33] Patil, D., Chandam, D., Mulik, A., Patil, P., Jagadale, S., Rajni, K., Gupta, V. and Deshmukh, M. (2014) Novel Brønsted Acidic Ionic Liquid ([CMIM][CF 3 COO]) Prompted Multicomponent Hantzsch Reaction for the Eco-Friendly Synthesis of Acridinediones: An Efficient and Recyclable Catalyst. Catalysis Letters, 144, 949958. https://doi.org/10.1007/s10562-014-1202-Z

[34] Bing, Y.S. and Wu Wang, G. (2008) Solvent-Free Synthesis of Xanthenediones and Acridinediones. Arkivoc, 16, 1-8

[35] Janardhan, B., Rajitha, B. and Peter A.C. (2013) Poly (4-Vinylpyridinium) Hydrogen Sulfate Catalyzed an Efficient and Ecofriendly Protocol for the One-Pot Multicomponent Synthesis of 1,8-Acridinediones in Aqueous Medium. Journal of Che- 
mistry, 2013, Article ID: 850254.

[36] Polshettiwar, V., Baruwati, B. and Varma, R.S. (2009) Magnetic Nanoparticle-Supported Glutathione: A Conceptually Sustainable Organocatalyst. Chemical Communications, 14, 1837-1839. https://doi.org/10.1039/b900784a

[37] Baig, R.B.N. and Varma, R.S. (2013) Organic Synthesis via Magnetic Attraction: Benign and Sustainable Protocols Using Magnetic Nanoferrites. Green Chemistry, 15, 398-417. https://doi.org/10.1039/C2GC36455G

[38] Polshettiwar, V., Baruwati, B. and Varma, R.S. (2009) Nanoparticle-Supported and Magnetically Recoverable Nickel Catalyst: A Robust and Economic Hydrogenation and Transfer Hydrogenation Protocol. Green Chemistry, 11, 127-131. https://doi.org/10.1039/B815058C

[39] Polshettiwar, V. and Varma, R.S. (2010) Nano-Organocatalyst: Magnetically Retrievable Ferrite-Anchored Glutathione for Microwave-Assisted Paal-Knorr Reaction, Aza-Michael Addition, and Pyrazole Synthesis. Tetrahedron, 66, 1091-1097. https://doi.org/10.1016/j.tet.2009.11.015

Submit or recommend next manuscript to SCIRP and we will provide best service for you:

Accepting pre-submission inquiries through Email, Facebook, LinkedIn, Twitter, etc. A wide selection of journals (inclusive of 9 subjects, more than 200 journals)

Providing 24-hour high-quality service

User-friendly online submission system

Fair and swift peer-review system

Efficient typesetting and proofreading procedure

Display of the result of downloads and visits, as well as the number of cited articles

Maximum dissemination of your research work

Submit your manuscript at: http://papersubmission.scirp.org/

Or contact gsc@scirp.org 